\title{
Ultrastructure of the primary gill lamellae of Scomber australasicus infected by a didymozoid parasite
}

\author{
K. M. L. Perera \\ Department of Zoology, University of New England, Armidale, New South Wales, 2351, Australia
}

\begin{abstract}
Didymozoid parasites occupy the space between the basal lamina of the primary epithelium and the efferent artery of the primary gill lamellae. The response of the host, slimy mackerel, consists mainly in the formation of (1) a capsule around the worms; (2) a layer of columnar epithelial cells; (3) electron-dense filamentous bands around the nucleus of the epithelial cells of the capsule; and (4) additional chloride cells in the capsule. Additionally, subepithelial cells degenerate and amoeboid cells occur in the lumen of the capsule in response to didymozoan infection.
\end{abstract}

\section{INTRODUCTION}

Ultrastructural studies of the pathology of helminth parasites of fish are rare (see review by Rohde 1984). Hoole \& Arme (1982) studied cellular responses of roach Rutilus rutilus to a cestode, Ligula intestinalis. Roubal (1985) conducted studies on ectoparasites of the marine bream Acanthopagrus australis, and Wanstall et al. (1988) studied the pathology of an acanthocephalan, Pomphorhynchus laevis, in the alimentary tract of the stone loach Noemacheilus barbatulus. In this paper, I present electron microscopic data on the pathology due to a didymozoid gill parasite of the slimy mackerel Scomber australasicus. The pathological effects of the same parasite at light microscopic level were previously described by Perera (1992; preceding article).

\section{MATERIALS AND METHODS}

Slimy mackerel Scomber australasicus were caught in Jervis Bay, New South Wales, Australia. For transmission electron microscopy, primary gill filaments of $S$. australasicus infected by didymozoans were fixed in $2 \%$ glutaraldehyde and postfixed in $1 \% \mathrm{O}_{5} \mathrm{O}_{4}$. They were dehydrated in graded concentrations of ethanol. The absolute ethanol was replaced stepwise with Spurr's resin. Transverse ultra-thin sections (reflective index pale gold to silver colour; 50 to $70 \mathrm{~mm}$ thick) were cut using a Sorvall MT-2 ultramicrotome, mounted on copper grids coated with formvar, stained with uranyl acetate and lead citrate, and examined under a JEOL JEM-1200 EX electron microscope.

For scanning electron microscopy, specimens were fixed in $10 \%$ formaldehyde, dehydrated in graded concentrations of ethanol, critical-point dried, and palladium-gold sputtered. The specimens were examined under a JEOL JSM-35 scanning electron microscope.

\section{RESULTS}

Didymozoans are marine trematodes. The parasite species used in the present study belongs to the subfamily Nematobothriinae. It usually lives in pairs encapsulated on the efferent side of the primary gill filaments (Fig. 1), both in the internal and external primary gill lamellae. The parasites occupy a space between the basal lamina of the lateral epithelium and the efferent artery. The worms are encapsulated by the primary lateral epithelium and the efferent artery of the primary gill filament. The thickness of the epithelium (capsule wall) around the worms varies considerably even in one capsule (see Perera 1992).

A thick area of the epithelium about 7 to 8 cell layers thick is shown in Fig. $2 \mathrm{~A}$. Almost all cells are either circular or oval in shape. In some thick areas, the 


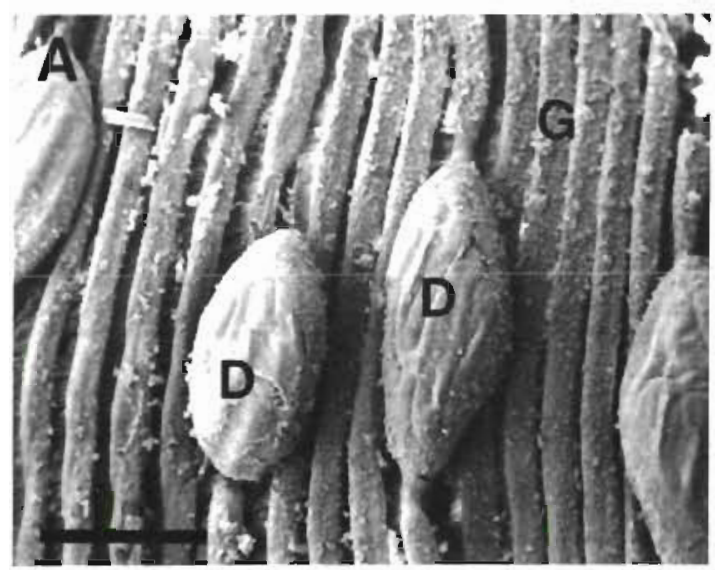

Fig. 1. Scomber australasicus. Scanning electron micrograph of primary gill filaments infected with didymozoans. G: primary gill filament (efferent side); D: didymozoan capsule. Scale bar $=1000 \mu \mathrm{m}$

outermost layers are flattened (Fig. 3C). Fig. 2 B shows a stretched area of the capsule. The epithelial cells in Figs. 2B \& $3 \mathrm{C}$ are highly flattened dorsoventrally due to the growth pressure of the parasite.

There are large intercellular spaces between the epithelial cells (Fig. 2A). Some epithelial cells have pseudopodia-like cytoplasmic processes, which extend into intercellular spaces (Fig. 2A). They contain scattered ribosomes and occasionally cytoplasmic filaments.

Unlike in the uninfected epithelium, most of the epithelial cells in the capsule have an electron-dense band around the nucleus, becoming thicker at the base of the cell (Fig. 2A). At higher magnification the dense material can be seen to consist of interwoven filaments, possibly in a dark granular matrix (Fig. 4 A). Almost all the cells in stretched areas have thicker electron-dense condensations (up to $0.4 \mu \mathrm{m}$ thick) than cells in the thicker areas of the capsule (up to $0.3 \mu \mathrm{m}$ thick).

The surface epithelial cells have nuclei of differing morphology, i.e. flattened, rounded, or bilobed (Figs. 2 $\& 3 \mathrm{C}$, also $6 \mathrm{~A}$ ) according to the site. The cytoplasm contains rough endoplasmic reticulum (rER), scattered ribosomes, vacuoles, and a few mitochondria (Fig. $2 \mathrm{C}$ ). A few small secretory granules are also present and a band of cytoplasmic filaments is found in most of the surface epithelial cells (Fig. 2C). Small microvilli occurring at the surface are not as prominent as in uninfected surface epithelial cells (Figs. 2B, C \& $3 \mathrm{~A}, \mathrm{~B}$, also $6 \mathrm{~A})$.

A continuous layer of columnar epithelial cells is found close to the basal lamina. These cells have large jrregularly shaped nuclei in thicker areas (Fig 2A) and flattened nuclei in stretched areas (Fig. $2 \mathrm{~B}$ ). The shape of the cells changes from place to place due to the growth pressure of the worms. The cytoplasm of the columnar (basal) epithelial cells is very similar to that of surface epithelial cells. They have a thick band of filaments and relatively more mitochondria than surface epithelial cells and most mitochondria are placed between the nucleus and the band of filaments (Figs, 2B \& 4A). Large numbers of cytoplasmic filaments and bundles of filaments are found outside the filamentous band and in the upper part of the cells (Fig. 4A). Enlarged cytoplasmic filaments are shown in Fig. 4 B.

There are highly electron-dense, dark nucleated epithelial cells in the middle area of the epithelium (Fig. 2A). The nuclei are rounded with a thick peripheral band of heterochromatin and large chromocenters. The cytoplasm of these cells has vacuoles, scattered ribosomes and a few mitochondria. Some of the cells have a few pseudopodia-like cytoplasmic processes (Fig. 4 C). Cytoplasmic filaments are not evident in the dark nucleated epithelial cells.

A few mucus cells are found in the outermost layer of the epithelium (Fig. 4D). Large secretory vesicles with a wide range in electron density are seen in the cell (Fig. 4D) and no ultrastructural changes are observed in mucus cells due to didymozoid infection.

Acidophilic cells are rare in the tissue infected with didymozoans in the present study.

Type 1 cells occur among the epithelial cells (Figs, 2A \& 3A, B). Most of them are found in the surface area of the epithelium (Fig. $3 \mathrm{~A}, \mathrm{~B}$ ). On one occasion a detached type 1 cell was seen in the mucus close to the surface of the epithelium (Fig. $3 \mathrm{~A}$ ). There is no obvious increase or decrease in their number due to the didymozoid infection.

Chloride cells are present in the lateral epithelium (didymozoan capsule) as well as in the interlamellate epithelium. Some of them are located in the outermost layer (Fig. 3C), and some among other epithelial cells. They have very large mitochondria and a tubular reticulum (Fig. 3 C, D). Some cells at the periphery are evidently degenerating (Fig. $3 \mathrm{C}$ ). In uninfected filaments chloride cells are observed only in the interlamellate epithelial region.

The basal lamina of the lateral epithelium of the filament infected with didymozoans is highly stretched. It does not show folds like the basal lamina of the lateral epithelium of uninfected filaments. The thickness of the basal lamina of the capsule may vary from place to place. However, the thickness of the outer electron-dense layer does not vary, only that of the layers of connective tissue fibrils. A thickened part of the basal lamina of the gill filament infected with didymozoans is shown in Fig. $5 \mathrm{~A}$. There are patches of cytoplasm among the connective tissue fibrils (Fig. $5 \mathrm{~A}$, $B$ ). Some have long profiles of $r E R$ and mitochondria (Fig. 5D), and some have pseudopodia-like cytoplasmic projections. Also, some cells interpreted as 


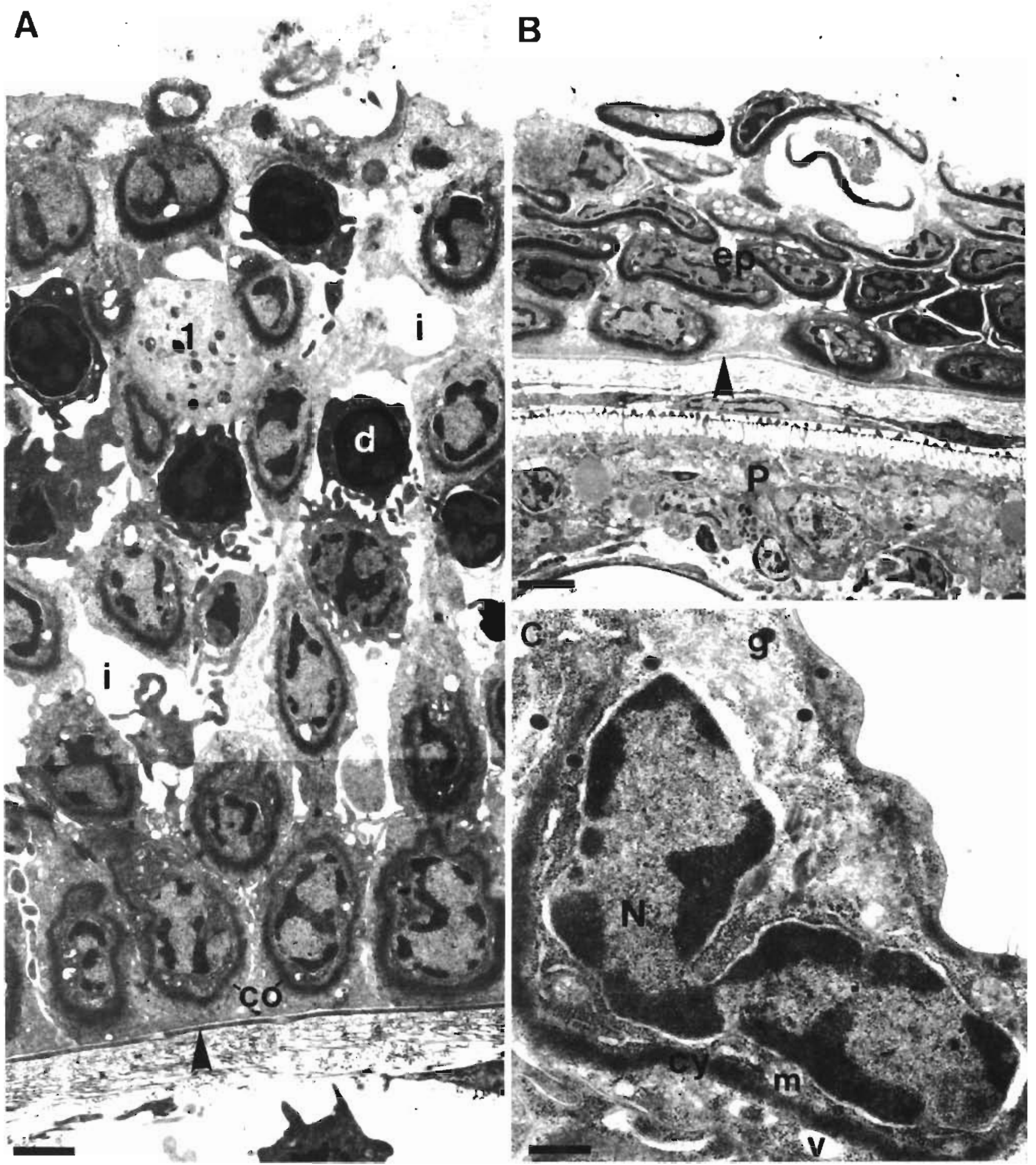

Fig. 2. Scomber australasicus. (A) Transverse section of thick area of the didymozoan capsule. Note intercellular spaces and closely packed columnar epithelial cell layer close to the basal lamina. There is a degenerated cell near the surface of the epithelium. co: columnar epithelial cells; d: dark nucleated cell; arrow head: basal lamina; i: intercellular spaces; 1 : type 1 cell. Scale bar $=2 \mu \mathrm{m}$. (B) Transverse section of a stretched area of the didymozoan capsule. Note a few intercellular spaces, perhaps due to stretching of the epithelium, and a degenerating cell close to the surface of the epithelium. ep: flattened epithelial cells; arrow head: basal lamina; P: parasite. Scale bar $=3 \mu \mathrm{m}$. (C) Transverse section of surface epithelial cell. N: nucleus; cy: electrondense thin band; $v$ : vacuole; $\mathrm{m}$ : mitochondrion; $\mathrm{g}$ : small secretory granule. Scale bar $=0.5 \mu \mathrm{m}$ 

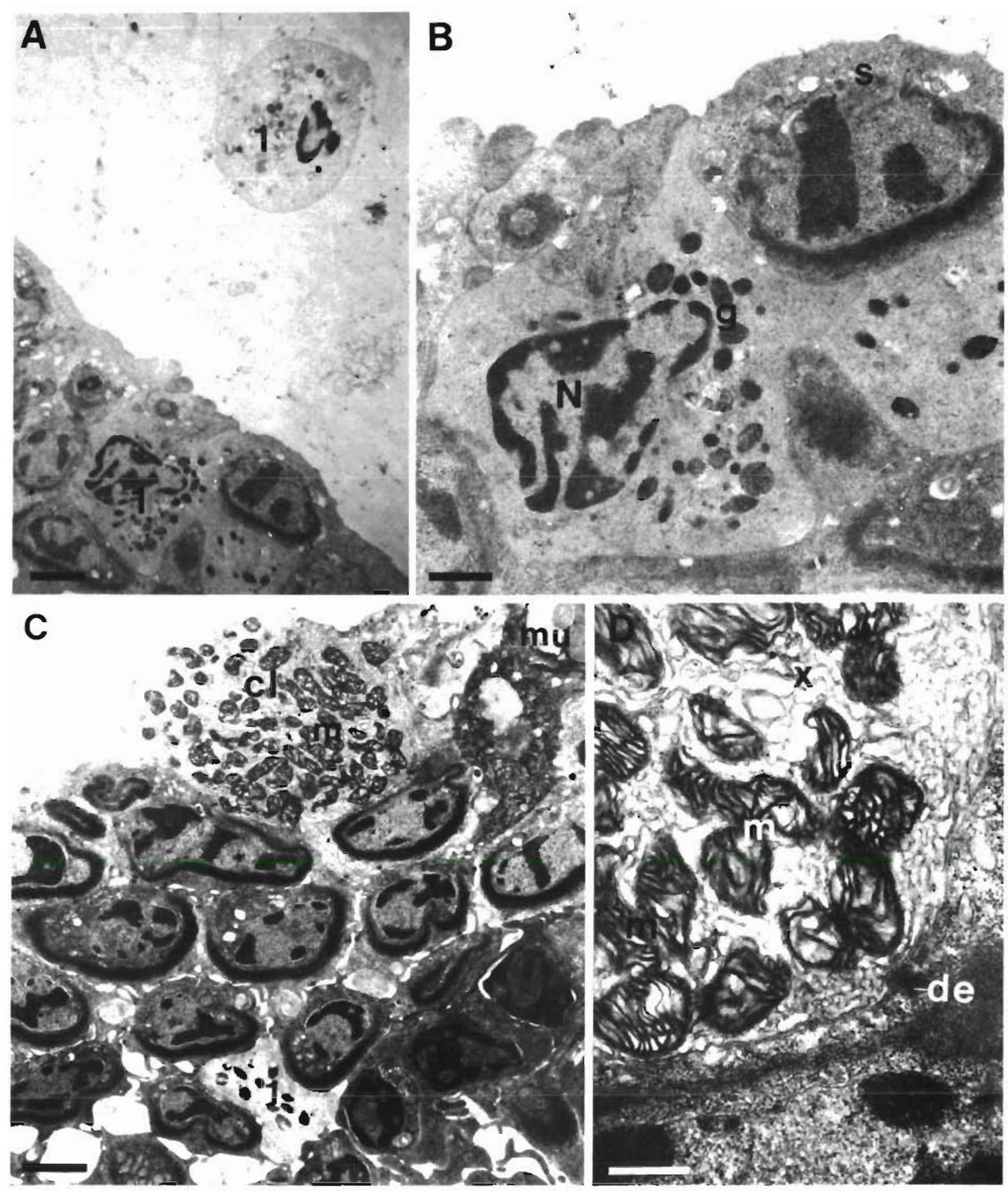

Fig. 3. Scomber australasicus. (A) Transverse section of surface epithelium with type 1 cells. Note detached type 1 cell close to the surface. 1: type 1 cells. Scale bar $=2$ um. (B) Type 1 cell close to the surface of the epithelium (capsule), no cell junctions were seen. N: nucleus; g: secretory granules; s: surface epithelial cell. Scale bar $=1 \mu \mathrm{m}$. (C) Transverse section of chloride cell in the surface of the didymozoan capsule. cl: chloride cell $\mathrm{m}$ : mitochondria: 1 : type 1 cell mu: mucus cell. Scale bar $=2$ um. (D) Part of the chloride cell shown in (C) enlarged. Note a desmosome-like structure between chloride cell and the epithelial cell (de). $m$; mitochondna; $\mathrm{x}$ : tubular reticulum. Scale bar $=0.5 \mathrm{um}$ 


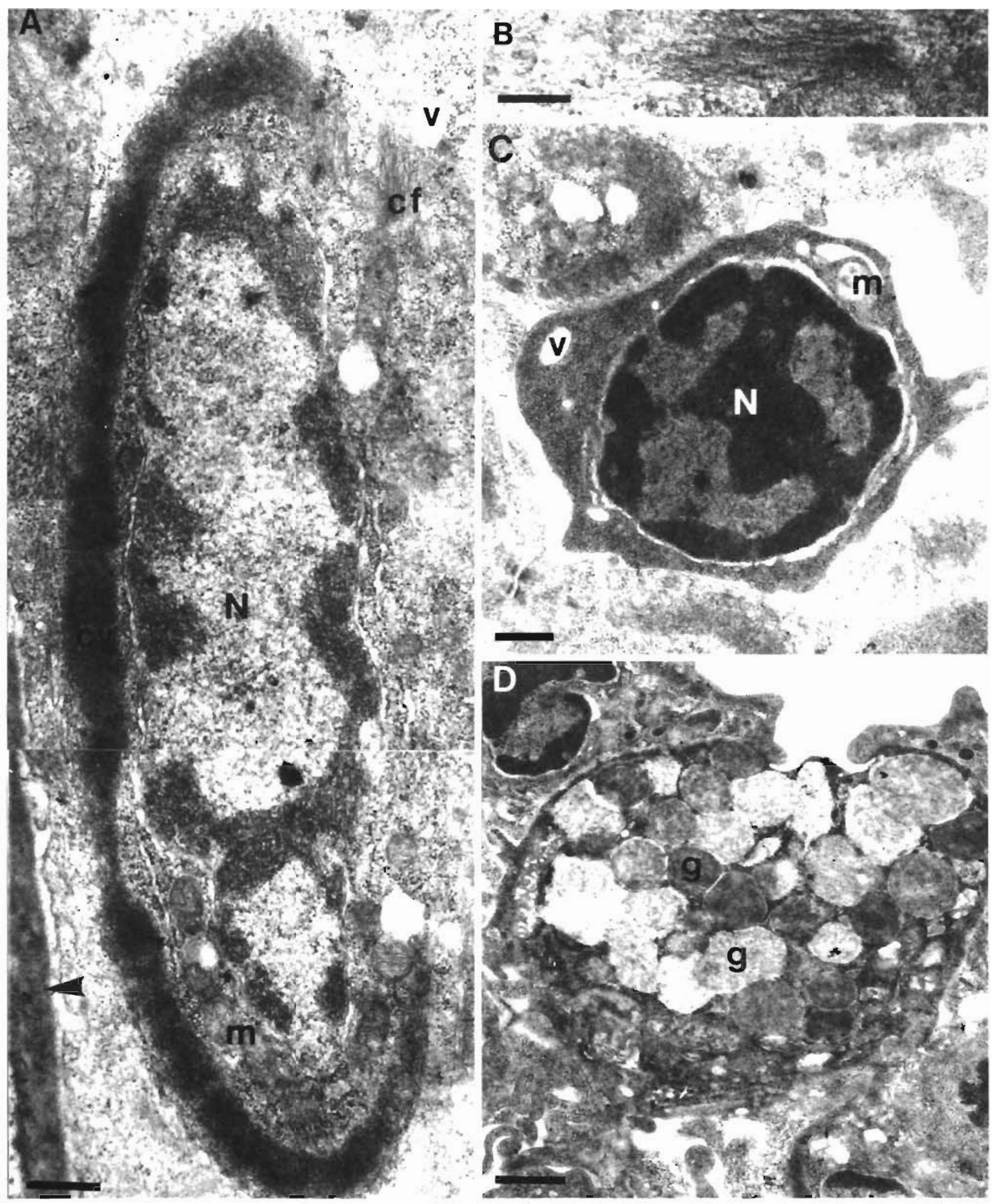

Fig. 4. Scomber australasicus. (A) Enlarged transverse section of basal epithelial cell. N nucleus, cy: electron-dense band; $\mathrm{v}$ : vacuole; $\mathrm{m}$ : mitochondria; cf: cytoplasmic filaments, arrow head basal lamina. Scale bar $=05 \mu \mathrm{m}$. (B) Cytoplasmic tilaments. Scale bar $=0.2 \mu \mathrm{m}$. (C) Dark nucleated cell $\mathrm{N}$. large nucleus, m: mitochondrion; v vacuole Scale bar $=05 \mu \mathrm{m}$ (D) Transverse section of a mucus cell; no nucleus was seen in this section Note almost all of the cell is filled with mucus secreting vesicles. 


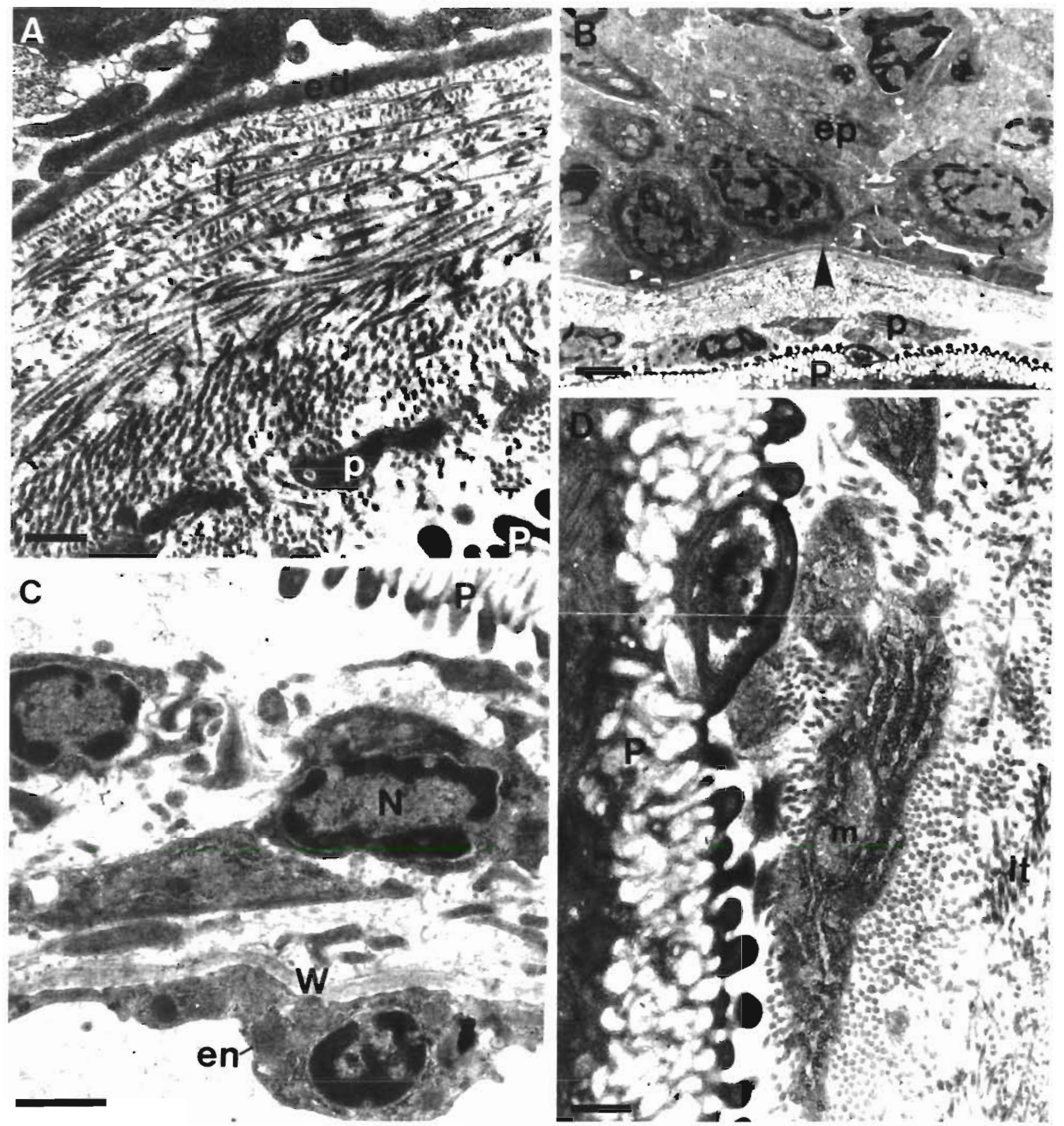

Fig. 5. Scomber australasicus. (A) Transverse section of basal lamina ed; electron-dense layer; lt: longitudinal and transverse tissue fibrils; p: patches of cytoplasm; P. parasite Scale bar $=0.5 \mu \mathrm{m}$. (B) Transverse section showing patches of cytoplasm between basal lamina and parasite. ep: epithelium; arrow head: basal lamina; : patches of cytoplasm; P: parasite. Scale bar = 2 um. (C) Transverse section of subepithelial and perhaps degenerating host cells between parasite and efferent blood vessel Note stretched wall of the efferent blood vessel (W). N: nucleus; P: parasite; en: endothelium of the blood vessel. Scale bar $=1 \mu \mathrm{m}$ (D) Patch of cytoplasm with mitochondria and rER. $\mathrm{m}$ : mitochondrion; $*$ : rough endoplasmic reticulum; P: parasite; lt: longitudinal and transverse tissue fibrils of basal lamina. Scale bar $=0.5 \mu \mathrm{m}$ 
degenerating are found between the parasite and the efferent blood vessel (Fig. 5C). Some of these cells have either flattened or rounded nuclei with a thick peripheral band of heterochromatin which is broken in some areas (Fig. 5 C). They also have pseudopodia-like cytoplasmic projections. The stretched wall of the efferent blood vessel is also evident (Fig. 5C).

Free amoeboid cells are observed in the lumen of the capsule. Most of them are seen close to the basal lamina (Fig. 6A). The shape of the cells may vary from place to place. Some are rounded (Fig. 6A.), and some are flattened (Fig. 5B). The nuclei of the most common amoeboid cell type are either rounded or flattened with a moderate amount of heterochromatin. Long profiles of $\mathrm{rER}$, scattered ribosomes, moderate to low electrondense small rounded granules and a few mitochondria are present in the less electron-dense cytoplasm. Small pseudopodia are also evident (Fig. 6B). These cells are probably neutrophils.

A second type of amoeboid cell, similar to type 1 cells, is found in the capsule. It has long pseudopodia (Fig. 6D). The nucleus of the cell has a moderate amount of heterochromatin. Moderately electrondense cytoplasm contains round to oval electron-dense granules, many of them spindle-shaped and with many filaments (Fig. 6D). There are also scattered ribosomes, a few mitochondria, vacuoles and small bundles of filaments (Fig. 6D). This cell differs from the neutrophil in the absence of well-developed profiles of rER and the presence of filamentous structure in the granules.

On one occasion a cell similar to the type 2 cell was found in the capsule (Fig. $7 \mathrm{~A}$ ). It has highly electrondense granules with electron-lucent rims around them, a few mitochondria, vacuoles, a few profiles of rER and a few scattered ribosomes in the cytoplasm. This cell also has small pseudopodia (Fig. 7 A).

Some amoeboid cells are also found in the space between different parts of the parasite (Fig. 6C). One cell is a neutrophil and the other resembles a type 1 cell.

Some areas of the wall of the efferent blood vessel are stretched (Fig. $5 \mathrm{C}$ ). This may be due to the growth of the parasite. The stretched endothelial cells and stretched elastic layer are evident (Fig. 5C). The connective tissue layer beneath the elastic layer, not visible as in the wall of the uninfected efferent blood vessel, may be due to stretching of the wall. Also the elastic layer does not show folds like that of the uninfected filament, and no muscle cells are observed beneath the elastic layer. The lumen of the efferent blood vessel contains red blood cells, neutrophils and monocytes.

No changes are apparent in the interlamellate region due to the didymozoan infection (Fig. $7 \mathrm{~B}$ ). The secondary lamellae are normal (Fig. 7 C, D).

\section{DISCUSSION}

This is the first electron microscopic study of the pathology induced by a gill-dwelling didymozoan. Lester (1980) and Eiras \& Rego (1987) studied the pathology of some didymozonas by means of light microscopy, and I examined the light microscopic pathology of the species described in the present paper (see Perera 1992). The parasite pair occupies a space between the basal lamina of the lateral epithelium and the efferent artery, where it is encapsulated by the primary lateral epithelium and the efferent artery of the primary gill filament (Perera 1992). The didymozoids do not secrete a cyst wall. When the worms become larger, they exert pressure against the capsule wall. Hence the capsule wall (lateral epithelium) stretches to accommodate them. The thinnest areas of the capsule are apparently subject to more pressure than others. Hence, thickness of the epithelium around the worms varies considerably even in one capsule, whereas the uninfected gill filaments have a relatively even lateral epithelium. Stretching leads to a change in the shape of the epithelial cells.

There were large intercellular spaces between epithelial cells in the thicker areas of the capsule, and some epithelial cells had pseudopodia-like cytoplasmic processes, absent in the uninfected lateral epithelium. When the lateral epithelium becomes stretched, some of the epithelial cells in the area may migrate to other areas, and pseudopodia-like structures of these cells may aid migration. Some of the epithelial cells had become detached from the surface (such as type 1 cells), and some others were degenerated (such as surface epithelial cells, chloride cells), possibly due to severe stretching of the capsule.

Bowers \& Alexander (1982) reported that bacteria can enter the fish through the gills. In the present study the thinness of the capsule epithelium due to severe stretching may facilitate entrance of pathogenic microorganisms. The columnar epithelial cell layer found in the capsule is probably a protective layer developed by the host against pathogenic micro-organisms, in addition to reinforcing the capsule.

Filamentous condensations in the epithelial cells due to parasitic infection, as found in the present study, have not been recorded by other authors. The formation of filaments, bundles of filaments, and electrondense filamentous bands in the cytoplasm of the epithelial cells appears to be due to the tissue reaction of the host to the parasite. The filamentous material formed in the epithelial cells is most probably collagen fibres. However, no histochemical tests were made to prove this. The cytoplasmic filamentous condensations may give additional strength to the epithelial cells, and the epithelium may thus resist the pressure produced 


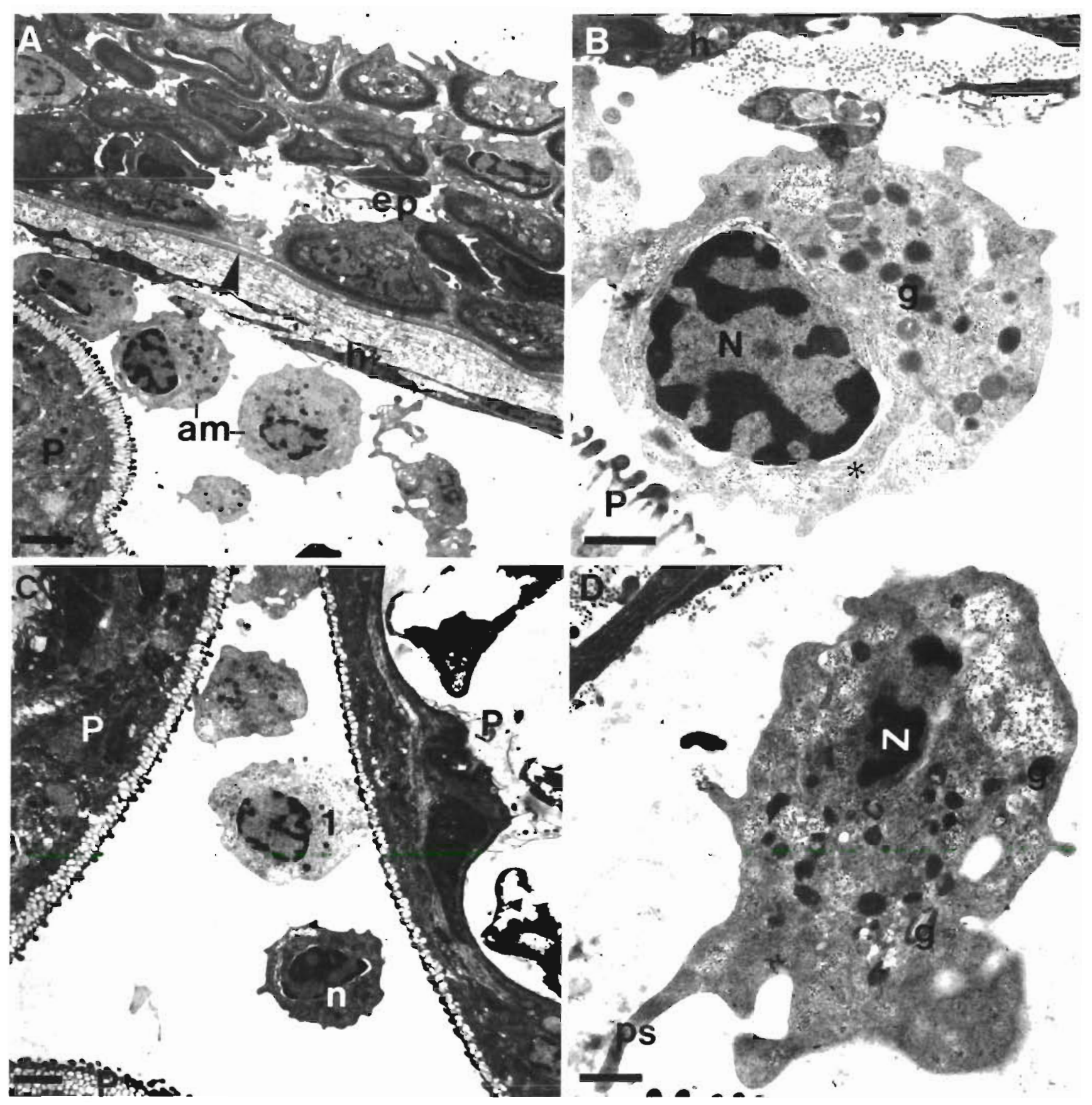

Fig. 6. Scomber australasicus. (A) Transverse section of free amoeboid cells (am) in the lumen of the capsule. ep: stretched epithelium; arrow head: basal Iamina; P: parasite; h. subepithelıal and perhaps degenerating host cells. Scale bar $=3 \mathrm{um}$. (B) Neutrophil. Note small pseudopodia. N: nucleus; *: rough endoplasmic reticulum; g: secretory granules; P: parasite; $h$ : subepithelial and perhaps degenerating host cell. Scale bar $=1 \mu \mathrm{m}$. (C) Amoeboid cells between parts of parasite. P: parasite; $\mathrm{n}$ : neutrophil; 1: type 1 cell. Scale bar $=2 \mu \mathrm{m}$. (D) Transverse section of a type 1 cell found in the lumen of the capsule. Note long pseudopodia (ps). N: nucleus; g: secretory granules. Scale bar $=1 \mu \mathrm{m}$

by the parasite during growth. This may be a reason that epithelial cells subjected to more pressure have thicker filamentous bands than the epithelial cells in the thicker areas.

Type 1 cells are mostly found in the surface area of the epithelium (capsule). On one occasion I observed a detached type 1 cell close to the surface of the epithelium. Cell junctions between type 1 cells and other epithelial cells were not observed. Hence, these cells could be migrating and intercellular spaces in the 

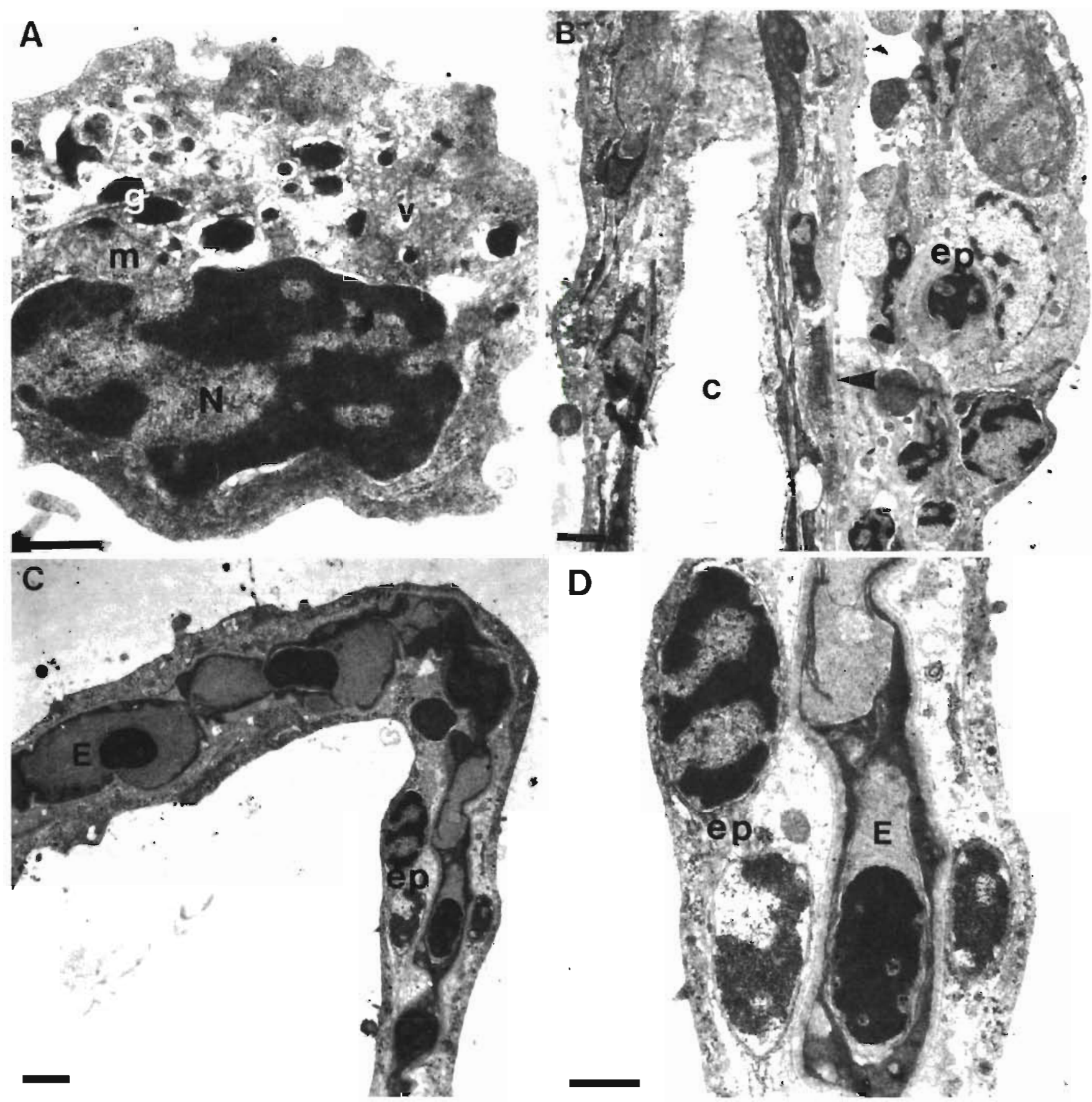

Fig. 7 Scomber australasicus. (A) Transverse section of type 2 cell found in the capsule $N$ nucleus; $g$. highly electron-dense secretory granules; $\mathrm{m}$ : mitochondrion; $v$. vacuole. Scale bar $=0.5 \mu \mathrm{m}$. (B) Transverse section of interlamellate region $\mathrm{c}^{*}$ cartılage; ep: epithelium; arrow head: basal lamina. Scale bar $=2 \mu \mathrm{m}$ (C) Part of secondary lamellae. E. erythrocyte; ep epithelium Scale

bar $=1 \mu \mathrm{m}$. (D) Part of the secondary lamellae shown in (C) enlarged. ep: epithelium; E. erythrocyte Scale bar $=1 \mu \mathrm{m}$

capsule may also have aided cell migration. Cells can also easily detach from the capsule to compensate for the stretching of the epithelium. No observations were made on type 1 cells detached from the unnfected lateral epithelium.

Parasitic infections reportedly decrease mucus cell concentration in the skin epidermis and the gllls of fishes (Robertson et al. 1981, Pottinger et al. 1984, Roubal et al. 1987, Wells \& Cone 1990). Benz (1980) reported an increase in mucus cell density in the epithelial layer of shortfin makos Isurus oxyrinchus due to the copepod Nemesis lamna. However, there was no 
obvious increase or decrease in the number of mucus cells due to parasitic infection in the present study.

The acidophilic cells were rare in the tissue infected with didymozoans, but in developing stages of parasites I have observed a number of acidophilic cells in the capsule wall (see Perera in press).

Langdon et al. (1985) described chloride cell hyperplasia in the gills of bony bream Nematalosa erebi during an epizootic of the ciliate Chilodonella hexasticha. This response was also noted for didymozoid infections in the present study. Roubal (1989) reported degenerating chloride cells due to ectoparasites on the gills of marine bream Acanthopagrus australis. Degenerating chloride cells were similarly observed in the didymozoan capsule of $S$. australasicus. However, an increase in the number of chloride cells was not noted by Roubal (1989). The chloride cells are thought to function in ionic regulation (Langdon et al. 1985). The formation of the additional chloride cells in the lateral epithelium is most probably due to didymozoan infection. The infection may change the permeability of the gill tissue, and it is probable that formation of these additional chloride cells can restore ionic homeostasis. The degeneration of some chloride cells in the surface of the capsule probably compensates for the severe stretching of the capsule wall.

In uninfected gill filaments, there were large numbers of subepithelial cells in the area between the efferent artery and the lateral epithelium, but in infected filaments parasites occupied this space, and the subepithelial cells were probably digested by the parasites. Patches of cytoplasm, seen between the connective tissue fibrils of the basal lamina (inner edge of the capsule), may be residues of degenerated subepithelial cells caused by the presence of the parasites.

Leucocytes have been previously reported in piscine inflammatory responses to infection by parasites (Hawkins et al. 1981. Hoole \& Arme 1982, Roubal 1986. Wanstall et al. 1988, Morrison \& Poynton 1989). In the present study, free amoeboid cells (i.e. neutrophils, type 1 cells and a type 2 cell) were observed, which could be an inflammatory response of the host to the didymozoid parasite. Hoole \& Arme (1982) reported that leucocyte cell types (L1, L2, L3) were phagocytic, and Stehr \& Whitaker (1986) observed occasional phagocytes located at the edge of the encapsulated plasmodia in the muscle of Pacific whiting. However, in the present study no phagocytosis was observed in the capsule.

Eiras \& Rego (1987) observed haemorrhages and lymphocyte infiltration in some of the nodules of Nematobothrium scombri in the operculum of Scomber japonicus, but no haemorrhages or lymphocyte infiltration were observed in the present study. Only neutrophils, type 1 cells and a type 2 cell were observed.
Lester (1980) observed leucocytes in Platycephalus fuscus tissue adjacent to haemorrhaging capsules of Neometadidymozoon helicis, but not surrounding or attaching to the worms themselves.

According to Ellis (1977), neutrophils were more abundant in infected tissue than in normal tissue. The present study agrees with this, since in the uninfected gill filaments extra-vascular neutrophils were rare and several neutrophils were present in the didymozoan capsule. However, in the uninfected filament, type 1 and type 2 cells were common in the area occupied by the parasites.

In the present study the presence of amoeboid cells within the capsule surrounding the parasite may indicate an inflammatory response. However, the inflammatory cells of the slimy mackerel were never observed to penetrate the tegument of the didymozoid worms, and there was no sign of damage to the parasites. This suggests that although the slimy mackerel reacts to the infection of didymozoans by an inflammatory response, it is not capable of rejecting the parasites, at least once they have reached an advanced stage of development.

Acknowledgements. I sincerely thank my supervisor Associate Professor Klaus Rohde for his guidance, critical comments and for carefully reading the manuscript; $\mathrm{P}$. Carlic and R. Porter of the Electron Microscope Unit of University of New England who gave me advice on the technical aspects of electron microscopy; $Z$. Enoch for his assistance with the photographic work; and $C$. Hayward for proofreading the manuscript. This study was supported by the Australian International Development Assistance Bureau.

\section{LITERATURE CITED}

Benz, G. W. (1980). Tissue proliferations associated with Nemesis lamna Risso, 1826 (Copepoda: Endactylinidae) infestations on the gill filaments of shortfin makos (Isurus oxyrinchus Rafinesque). J. Fish Dis. 3: 443-446

Bowers, A., Alexander, J. B. (1982). In vitro and in vivo passage of bacteria across restricted areas and isolated tissues of trout, Salmo trutta L and S. gairdneri Richardson. J. Fish Dis. 5: 145-151

Eiras, J. C., Rego, A. A. (1987). The histopathology of Scomber japonicus infection by Nematobothrium scombri (Trematoda Didymozoidae) and of larval anisakid nematode infections in the liver of Pagrus pagrus. Mem. Inst. Oswaldo Cruz 82 (2): 155-159

Ellis, A. E. (1977). The leucocytes of fish: a review. J. Fish Biol. 11: 453-491 Hawkins, W. E., Solangi, M. A., Overstreet, R. M. (1981). Ultrastructural effects of the coccidium, Eimeria funduli Duszynski, Solangi and Overstreet, 1979 on the liver of killifishes. J. Fish Dis. 4. 281-295

Hoole, D., Arme, C. (1982). Ultrastructural studies on the cellular response of roach, Rutilus rutilus L., to the plerocercoid larva of the pseudophyllidean cestode, Ligula intestinalis. J. Fish Dis. 5: 131-144

Langdon, J. S., Gudkovs, N., Humphrey, J. D., Saxon, E. C. (1985). Deaths in Australian freshwater fishes associated 
with Chilodonella hexasticha infection. Aust. vet. J. 62 (12): 409-413

Lester, R. J. G. (1980). Host-parasite relations in some didymozoid trematodes. J. Parasitol. 66 (3): 527-531

Morrison, C. M., Poynton, S. L. (1989). A new species of Goussia (Apicomplexa, Coccidia) in the kidney tubules of the cod, Gadus morhua L. J. Fish Dis. 12: 533-560

Perera, K. M. L. (1992). Light microscopic study of the pathology of a species of didymozoan, Nematobothrinae gen. sp., from the gills of slimy mackerel Scomber australasicus. Dis. aquat. Org. 13: 103-109

Pottinger, T G. Pickering, A. D., Blackstock, N. (1984). Ectoparasite induced changes in epidermal mucification of the brown trout Salmo trutta L. J. Fish Biol. 25: 123-128

Robertson, D. A., Roberts, R. J., Bullock, A. M. (1981). Pathogenesis and autoradiographic studies of the epidermis of salmonics infested with Ichtyobodo necator (Henneguy, 1883). J. Fish Dis. 4: 113-125

Rohde, K. (1984). Diseases caused by metazoans: Helminths. In: Kinne, O. (ed.) Diseases of marine animals, Vol. IV, Part 1. Biologische Anstalt Helgoland, Hamburg, p. 193-320

Roubal, F. R. (1985). Histological, cytological and morphomet ric aspects of ectoparasite pathology on the marine bream, Acanthopagrus australis. Ph.D. thesis, University of New England, Armidale

Roubal, F. R. (1986). The histopathology of the copepod,

Responsible Subject Editor: W. Körting, Hannover, Germany
Ergasilus lizae Krøyer, on the pseudobranchs of the teleost. Acanthopagrus australis (Günther) (Family Sparidae). Zool. Anz. 217: 65-74

Roubal, F. R. (1989). Comparutrve pathology of some monogenean and copepod ectoparasites on the gills of Acanthopagrus australis (family Sparidae). J. Fish Biol. 34: 503. 514

Roubal, F. R., Bullock, A. M., Robertson, D. A., Roberts, R. J. (1987). Ultrastructural aspects of infestation by Ichthyobodo necator (Henneguy, 1883) on the skin and gills of the salmonids Salmo salar L. and Salmo gairdneri Richardson. J. Fish Dis. 10: 181-192

Stehr, C., Whitaker, D. J. (1986). Host-parasite interaction of the myxosporeans Kudoa paniformis Kabata \& Whitaker, 1981 and Kudoa thyrsites (Gilchrist, 1924) in the muscle of Pacific whiting, Merluccius productus (Ayres): an ultrastructural study. J. Fish Dis. 9: 505-517

Wanstall, S. T., Thomas, J. S., Robotham, P. W. J. (1988). The pathology caused by Pomphorhynchus laevis Müller in the almentary tract of the stone loach. Noemacheilus barbatulus (L.). J. Fish Dis. 11 511-523

Wells, P. R., Cone, D. K. (1990). Experimental studies on the effect of Gyrodactylus colemanensis and G. salmonis (Monogenea) on density of mucous cells in the epidermis of fry of Oncorhynchus mykiss. J. Fish Biol. 37 : 599-603

Manuscript first received: January 10, 1992

Revised version accepted: April 16, 1992 